\title{
ANALISIS PERBANDINGAN PEREKONOMIAN PADA EMPAT KORIDOR DI PROPINSI JAWA TIMUR
}

\author{
Oleh: \\ Zainal Arifin \\ Fakultas Ekonomi Universitas Muhammadiyah Malang \\ E-mail/No. Hp: azainala@yahoo.com/08155528001
}

\begin{abstract}
The purpose of this study is to identify how the pattern of economic growth at the district level in each of the corridors in the province of East Java; identify what sectors could be developed in an effort to determine development priorities at the district level in each corridor in East Java Province, and to compare the level of the economy on four corridors in East Java Province. Based on comparative analysis of the economy can be explained that the North South Corridor has on the economy ranked first, followed by Southwest corridor, then the Eastern Corridor and the final ranking of the North Corridor
\end{abstract}

Keywords: Regions mainstay, leading sector, typology Klassen, $L Q$

\section{PENDAHULUAN}

Pembangunan ekonomi daerah adalah suatu proses di mana Pemerintah Daerah dan masyarakatnya mengelola sumber daya yang ada dan membentuk suatu pola kemitraan antara Pemerintah Daerah dengan sektor swasta untuk menciptakan suatu lapangan kerja baru dan merangsang perkembangan kegiatan ekonomi (pertumbuhan ekonomi) dalam wilayah tersebut. Sebagai tolok ukur keberhasilan pembangunan dapat dilihat dari pertumbuhan ekonomi, struktur ekonomi dan semakin kecilnya ketimpangan pendapatan antar penduduk, antardaerah dan antar sektor. Akan tetapi pada kenyataanya bahwa pertumbuhan ekonomi tidak selamanya diikuti pemerataan secara memadai.

Di negara-negara sedang berkembang, perhatian utama terfokus pada dilema komplek antara pertumbuhan versus distribusi pendapatan. Keduanya sama-sama penting, namun hampir selalu sulit diwujukan bersamaan. Pengutamaan yang satu akan menuntut dikorbankanya yang lain. Pembangunan ekonomi mensyaratkan Gross national Product $(G N P)$ yang tinggi dan untuk itu tingkat pertumbuhan yang tinggi merupakan pilihan yang harus diambil. Namun yang menjadi masalah bukan hanya soal bagaimana cara memacu pertumbuhan, tetapi juga siapa yang melaksanakan dan berhak menikmati hasil-hasilnya. Penanggulangan kemiskinan/kesenjangan pendapatan kini merupakan masalah pokok dalam pembangunan dan sasaran utama kebijakan pembangunan di banyak negara, (Todaro,2000:177).

Hal tersebut di atas selalau terjadi karena pembangunan, dalam lingkup negara secara spasial tidak selalu berlangsung sistemik. Beberapa daerah mencapai pertumbuhan cepat, sementara beberapa daerah lain mengalami peetumbuhan yang lambat. Daerahdaerah tersebut tidak mengalami kemajuan yang sama di sebabkan oleh karena kurangnya sumber-sumber yang 
di miliki, adanya kecenderungan peranan modal (investor) memilih daerah perkotaan atau daerah yang telah memiliki fasilitas seperti sarana perhubungan, jaringan listrik, jaringan telekomunikasi, perbankan, asuransi, juga tenaga kerja yang terampil di samping itu adanya ketimpangan redistribusi pembagian pendapatan dari pemerintah pusat kepada daerah.

Pemerintah Daerah di Indonesia telah mengalami perubahan seiring dengan di berlakukanya otonomi daerah, dengan mendekatkan pembuatan keputusan ke daerah, Pemerintah Pusat telah memberikan kewenangan kepada Pemerintah Daerah baik untuk mengatur urusan pembangunan ekonominya sendiri. Pemberlakuan otonomi daerah juga berarti Pemerintah Daerah harus memiliki rencana ekonomi daerah yang baik untuk menyediakan kesejahteraan bagi penduduknya. UU No. 25 tahun 1999 tentang Perimbangan Keuangan antara Pemerintah Pusat dan Daerah, akan membawa angin segar bagi daerah untuk dapat menggali dan mengembangkan potensi ekonomi secara mandiri sehingga ketimpangan antar penduduk, antardaerah dan antar sektor secara bertahap dapat diperkecil.

Pertumbuhan ekonomi Jawa Timur sebagai salah satu indikator pembangunan yang diukur dengan produk domestik regional bruto (PDRB) selama 5 tahun terakhir (2004-2008) mengalami pertumbuhan yang cukup stabil pada kisaran 5\%. Pada tahun 2004 pertumbuhan ekonomi Jawa Timur sebesar 5,83\%, pada tahun 2005 dan 2006 mencapai 5,84\% dan 5,80\%, sedangkan pada tahun 2007 dan 2008 mencapai $6,11 \%$ dan $5,90 \%$.

Propinsi Jawa Timur sendiri terbagi menjadi 38 Kabupaten/Kota, 29 Kabupaten dan 9 Kota. Propinsi Jawa Timur terbagi lagi menjadi beberapa koridor yang meliputi kabupaten/kota yang ada di Propinsi Jawa Timur, yaitu: Koridor Utara Selatan terdiri dari Gresik - Surabaya - Sidoarjo - Mojokerto Pasuruan - Malang - Blitar.

Koridor Barat Daya terdiri dari Jombang - Kediri - Tulungagung Trenggalek - Nganjuk - Madiun Ponorogo - Pacitan - Magetan.

Koridor Timur terdiri dari Probolinggo - Situbondo - Bondowoso Lumajang - Jember - Banyuwangi.

Koridor Utara terdiri dari Lamongan - Tuban - Bojonegoro Ngawi - Bangkalan - Sampang Pamekasan - Sumenep.

Percepatan pertumbuhan daerah bisa dicapai antara lain dengan memicu pusat-pusat pertumbuhan (growth poles) yang akan mendorong pertumbuhan daerah-daerah sekitarnya. Daerah-daerah biasanya sulit untuk berkembang cepat secara bersamaan. Pusat pertumbuhan diperlukan sebagai perangsang bagi pertumbuhan daerah sekitarnya. Penelitian ini akan menganalisis perbandingan perekonomian pada empat koridor di Propinsi Jawa Timur.

\section{METODE PENELITIAN}

Alat analisis Tipologi Klassen digunakan untuk mengetahui gambaran tentang pola dan struktur pertumbuhan ekonomi masing-masing daerah. Tipologi Klassen pada dasarnya membagi daerah berdasarkan dua indikator utama, yaitu pertumbuhan ekonomi daerah dan pendapatan perkapita daerah. Dengan menentukan rata-rata pertumbuhan ekonomi sebagai sumbu vertikal dan rata-rata pendapatan per kapita sebagai sumbu horizontal, daerah yang diamati dapat dibagi menjadi empat klasifikasi, yaitu: daerah cepat maju dan cepat tumbuh (high growth and high income), daerah maju tapi tertekan (high income but low growth), daerah berkembang cepat (high growth but low income), dan daerah 
relatif tertinggal (low growth and low income) (Syafrizal, 1997: 27-38; Kuncoro, 1993: Hill, 1989).

Tabel 1. Matrik Klasifikasi Pertumbuhan Ekonomi Menurut

Tipologi Klassen

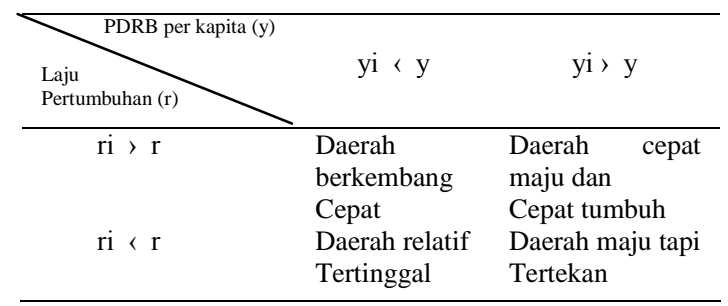

Keterangan : ri = laju pertumbuhan

PDRB kabupaten/kota $\mathrm{i}$

$\mathrm{r}=$ laju pertumbuhan total PDRB Jawa

Timur

yi= pendapatan perkapita kabupaten/kota i

$\mathrm{y}=$ pendapatan perkapita Jawa Timur

Analisis Location Quotient (LQ), Dengan alat analisis location question (LQ) ini dapat diketahui sektor ekonomi unggulan Kabupaten/Kota di empat Koridor yang ada di Propinsi Jawa Timur dari sisi kontribusi. Formulasi dari tehnik analisis tersebut adalah :

$$
L Q=\frac{\mathrm{Xr} / \mathrm{RVr}}{X n / R V n}
$$

Keterangan:

LQ = Location Quotient (hasil bagi lokasi)

$\mathrm{Xr}=$ Sumbangan sektor $\mathrm{i}$ daerah studi k (kabupaten/kota) dalam pembentukan Produk Domestik Regional Riil daerah studi.

$\mathrm{RVr} \quad=$ Produk Domestik Regional Riil total di semua sektor daerah studi.

$\mathrm{Xn}=$ Sumbangan sektor $\mathrm{i}$ daerah referensi (koridor propinsi) dalam pembentukan Produk Domestik Regional Riil daerah referensi.

$\mathrm{RVn}=$ Produk Domestik Regional Riil total di semua sektor daerah referensi.
Semakin tinggi nilai LQ suatu sektor berarti semakin pula competitif advantage daerah yang bersangkutan dalam mengembangkan sektor tersebut. Dari hasil perhitungan yang diperoleh, dapat dirtikan dalam tiga kategori, yaitu: Bila nilai LQ lebih kecil atau sama dengan 1, menunjukkan bahwa sektor tersebut bukan sektor unggulan. Karena laju pertumbuhan sektor i di daerah studi adalah lebih kecil laju pertumbuhan sektor yang sama di daerah referensi.

Bila nilai LQ lebih besar dari 1, menunjukkan bahwa sektor tersebut adalah sektor unggulan yang dapat dikembangkan lebih lanjut oleh daerah studi k. Karena laju pertumbuhan sektor i di daerah studi adalah lebih besar dibandingkan dengan laju pertumbuhan sektor yang sama di daerah referensi.

Bila nilai LQ sama dengan 1, maka menunjukkan bahwa spesialisasi sektor tersebut pada daerah studi sama dengan sektor yang sama di daerah referensi.

Untuk mengidentifikasi kawasan andalan, akan digunakan kombinasi analisis tipologi klassen dan LQ. Kecamatan yang termasuk dalam klasifikasi cepat tumbuh dan berkembang serta didukung adanya beberapa sektor yang memiliki keunggulan memungkinkan untuk dijadikan kawasan andalan.

Analisis perbandingan perekonomian dilakukan dengan penggabungan hasil analisi Tipologi Klassen dan LQ, kemudian ditentukan koridor mana yang memiliki peringkat pertama, kedua, ketiga dan keempat.

\section{PEMBAHASAN}

Dalam menganalisis perbandingan perekonomian pada empat koridor di Propinsi Jawa Timur, berikut akan dipaparkan pola pertumbuhan ekonomi, sektor yang bisa dikembangkan dalam upaya menentukan prioritas pembangunan serta menganalisa 
perbandingan perekonomian pada empat koridor di Propinsi Jawa Timur.

Berdasarkan hasil perhitungan menggunakan analisis Tipologi Klassen, maka dapat diketahui pola pertumbuhan ekonomi dari masing-masing kabupaten di empat koridor di Propinsi Jawa Timur.

Koridor Utara Selatan, Pola pertumbuhan ekonomi pada kabupaten di Koridor Utara Jawa Timur pada tahun 2005-2009 dapat diketahui kabupaten yang tergolong dalam daerah cepat maju dan cepat tumbuh (high growth and high income) adalah Kota Surabaya dan Kota Malang, yang tergolong daerah maju tapi tertekan (high income but low growth) adalah Kabupaten Sidorajo, Kota Batu dan Kabupaten Mojokerto, yang tergolong daerah berkembang cepat (high growth but low income adalah) Kabupaten Gresik, Kabupaten malang, Kota Blitar dan Pasuruan, dan yang tergolong daerah relatif tertinggal (low growth and low income) adalah Kabupaten Blitar.

Koridor Barat Daya, Pola pertumbuhan ekonomi pada kabupaten di Koridor Barat daya Jawa Timur pada tahun 2005-2009 dapat diketahui kabupaten yang tergolong dalam daerah cepat maju dan cepat tumbuh (high growth and high income) adalah Kota Kediri dan Kota Madiun, yang tergolong daerah maju tapi tertekan (high income but low growth) adalah Kabupaten Kediri, abupaten Nganjuk dan Kabupaten Madiun, yang tergolong daerah berkembang cepat (high growth but low income) adalah Kabupaten Jombang, Kabupaten Kediri, Kabupaten Ponorogo dan Kabupaten Magetan dan yang tergolong daerah relatif tertinggal (low growth and low income) adalah Kabupaten Pacitan dan Trenggalek.

Koridor Timur, Pola pertumbuhan ekonomi pada kabupaten di Koridor Timur Jawa Timur pada tahun 20052009 dapat diketahui kabupaten yang tergolong dalam daerah cepat maju dan cepat tumbuh (high growth and high income) adalah Kota Probolinggo dan Kabupeten Jember, yang tergolong daerah maju tapi tertekan (high income but low growth) adalah Kabupaten Banyuwangi dan Probolinggo, yang tergolong daerah berkembang cepat (high growth but low income) adalah Kabupaten Situbondo dan Kabupaten Bondowoso, dan yang tergolong daerah relatif tertinggal (low growth and low income) adalah Kabupaten Lumajang.

Koridor Utara, Pola pertumbuhan ekonomi pada kabupaten di Koridor Utara Jawa Timur pada tahun 20052009 dapat diketahui kabupaten yang tergolong dalam daerah cepat maju dan cepat tumbuh (high growth and high income) adalah Kabupaten Bojonegoro, yang tergolong daerah maju tapi tertekan (high income but low growth) adalah Kabupaten Lamongan, Kabupaten Tuban dan Kabupaten Sumenep, yang tergolong daerah berkembang cepat (high growth but low income) adalah, Kabupaten Ngawi dan Bangkalan dan yang tergolong daerah relatif tertinggal (low growth and low income) adalah kabupaten Sampang dan Kabupaten Pamekasan

Berdasarkan hasil perhitungan menggunakan analisis Location Question (LQ), maka dapat diketahui sektor yang dapat dikembangkan dalam upaya menentukan prioritas pembangunan pada masing-masing kabupaten di empat koridor di Propinsi Jawa Timur

Koridor Utara Selatan, Sektor yang dikembangkan dalam upaya menentukan prioritas pembangunan Kabupaten Gresik adalah sektor pertanian, pertambangan, indutri, jasajasa, Kota.Surabaya adalah sektor indutri, perdagangan, keuangan, jasajasa, Kabupaten Sidoarjo adalah sektor pertanian, indutri, keuangan, Kota Mojokerto adalah indutri, perdagangan, 
pengangkutan, Kabupaten Sidoarjo adalah sektor pertanian, indutri, konstruksi, jasa-jasa, Kota Pasuruan adalah sektor perdagangan, keuangan, jasa-jasa, Kabupaten Pasuruan adalah sektor pertanian, pengangkutan, jasajasa, Kota Malang adalah sektor pertanian, pengangkutan, jasa-jasa, Kabupaten Malang adalah sektor pertanian, perdagangan, keuangan. Kota Batu adalah sektor pertanian, jasa-jasa, Kota Blitar adalah sektor konstruksi, perdagangan, keuangan. Dan Kabupaten Blitar adalah sektor pertanian, konstruksi.

Koridor Barat Daya, Sektor yang dikembangkan dalam upaya menentukan prioritas pembangunan Kabupaten Jombang adalah sektor pertanian, pengangkutan, Kota Kediri adalah sektor indutri, listrik, keuangan, Kabupaten Kediri adalah sektor pertanian, konstruksi, perdagangan, jasa-jasa, Kabupaten Tulungagung adalah sektor pertanian, konstruksi, Kabupaten Trenggalek adalah sektor perdagangan, jasa-jasa, Kabupaten Nganjuk adalah sektor pertanian, listrik, Kota Madiun adalah sektor perdagangan, keuangan, jasa-jasa, Kabupaten Madiun adalah sektor pertanian, listrik, Kabupaten Ponorogo adalah sektor pengangkutan, jasa-jasa, Kabupaten Pacitan adalah sektor pertanian, pertambangan, Kabupaten Magetan adalah sektor listrik, jasa-jasa.

Koridor Timur, Sektor yang dikembangkan dalam upaya menentukan prioritas pembangunan Kota Probolinggo adalah sektor pertanian, jasa-jasa, Kabupaten Situbondo adalah sektor pertambangan, indutri, pengangkutan, Kabupaten Bondowoso adalah sektor perdagangan, pengangkutan, , Kabupaten Lumajang adalah sektor perdagangan, pengangkutan, Kabupaten Jember adalah sektor pertanian, indutri, listrik,
Kabupaten Banyuwangi adalah sektor pertambangan, konstruksi, perdagangan, keuangan.

Koridor Utara, Sektor yang dikembangkan dalam upaya menentukan prioritas pembangunan Kabupaten Lamongan adalah sektor pertanian, konstruksi, jasa-jasa, Kabupaten Tuban adalah sektor pertambangan, listrik, Kabupaten Bojonegoro adalah sektor pertanian, pengangkutan, keuangan, Kabupaten Ngawi adalah sektor pertanian, konstruksi, Kabupaten Bangkalan adalah sektor pertanian, listrik, Kabupaten Sampang adalah sektor konstruksi, perdagangan, Kabupaten Pamekasan adalah sektor konstruksi, perdagangan, Kabupaten Sumenep adalah sektor pertanian, pertambangan, jasa-jasa.

Analisis perbandingan perekonomian dilakukan dengan penggabungan hasil analisi Tipologi Klassen dan LQ, kemudian ditentukan koridor mana yang memiliki peringkat pertama, kedua, ketiga dan keempat. Dari analisis Tipologi Klaasen dan LQ dapat dijelaskan bahwa Koridor Utara Selatan memiliki perekonomian pada peringkat pertama, kemudian disusul koridor Barat Daya, selanjutnya Koridor Timur serta pada peringkat terakhir yaitu Koridor Utara.

\section{PENUTUP}

Berdasarkan analisis Tipologi Klassen di empat koridor di Jawa Timur yang termasuk daerah berkembang cepat adalah Kota Surabaya, Kota Malang, Kota Kediri, Kota Madiun, Kota Probolinggo, Kabupeten Jember, dan Kabupaten Bojonegoro. Yang tergolong daerah maju tapi Kabupaten Sidorajo, Kota Batu, Kabupaten Mojokerto, Kabupaten Kediri, Kabupaten Nganjuk, Kabupaten Madiun, Kabupaten Banyuwangi, Kabupaten Probolinggo Kabupaten Lamongan, Kabupaten Tuban 
dan Kabupaten Sumenep. Yang tergolong daerah berkembang cepat (high growth but low income adalah) Kabupaten Gresik, Kabupaten Malang, Kota Blitar, Kota Pasuruan, Kabupaten Jombang, Kabupaten Kediri, Kabupaten Ponorogo, Kabupaten Magetan, Kabupaten Banyuwangi, Kabupaten Probolinggo, Kabupaten Ngawi dan Kabupaten Bangkalan. Yang tergolong daerah relatif tertinggal (low growth and low income) adalah Kabupaten Blitar, Kabupaten Pacitan, Kabupaten Trenggalek, Kabupaten Lumajang, Kabupaten Sampang dan Kabupaten Pamekasan.

Sedangkan berdasarkan analisis LQ, sektor yang paling banyak menjadi unggulan adalah pertanian disusul listrik, gas dan air bersih, bangunan, jasa-jasa, keuangan, persewaan dan jasa perusahan, angkutan dan komunikasi, perdagangan, hotel dan restoran, industri pengolahan, serta pertambangan dan penggalian.

Berdasarkan analisis perbandingan perekonomian dapat dijelaskan bahwa Koridor Utara Selatan memiliki perekonomian pada peringkat pertama, kemudian disusul koridor Barat Daya, selanjutnya Koridor Timur serta pada peringkat terakhir yaitu Koridor Utara

Dalam menetapkan kebijakan pembangunan dan pengembangan sektoral perekonomian daerah, hendaknya lebih memprioritaskan sektor unggulan yang dimiliki oleh masingmasing Kabupaten. Meskipun demikian sektor lainnya tetap mendapat perhatian secara proporsional sesuai dengan potensi dan peluang pengembangannya.

Pengembangan sektor unggulan hendaknya diarahkan pada upaya untuk menciptakan keterkaitan antar Kabupaten di empat koridor di Jawa Timur. Salah satu upaya yang dapat ditempuh adalah melalui penciptaan proses pertukaran komoditas antar daerah yang memungkinkan bergeraknya perekonomian secara bersama-sama.

\section{DAFTAR PUSTAKA}

Arifin, Zainal (2003), Pertumbuhan Ekonomi dan Ketimpangan antar kabupaten di Jawa Timur, Laporan Penelitian

Arifin, Zainal (2005), Ketimpangan dan Konvergensi antar kabupaten di Jawa Timur, Laporan Penelitian

Aswandi, H., \& Kuncoro, M. (2002). Evaluasi Penetapan Kawasan Andalan: Stusi Empiris di Kalimantan Selatan 1993-1999. Jurnal Ekonomi dan Bisnis Indonesia, 17(1).

Arsyad, Lincolin, 1999. Pengantar Perencanaan dan Pembangunan Ekonomi Daerah, Edisi Pertama, Penerbit PBFE-Universitas Gadjah Mada, Yogyakarta.

Boediono, 1999. Teori Pertumbuhan Ekonomi, Seri Sinopsis, Edisi Pertama, Cetakan Keenam, BPFE, Yogyakarta.

Kuncoro, Mudrajad, 2000. Ekonomi Pembangunan (Teori, Masalah dan Kebijakan), Edisi Pertama, UPP AMP YKPN, Yogyakarta.

Maskun, Sumitro. H, 1996. Pengembangan Ekonomi Regional; Tantangan dan Prospeknya Bagi Perekonomian Nasional, Manajemen Usahawan Indonesia No. 12, Tahun XXV, 10-13. 
Richardson, Harry W, 1991. DasarDasar Ilmu Ekonomi Regional (terjemahan oleh : Paul Sihotang), LPFE-UI, Jakarta.

Sjafrizal, 1997. "Pertumbuhan Ekonomi Dan Ketimpangan Regional Wilayah Indonesia Bagian Barat", Prisma, No.3, 27-38.

Soepono,Prasetyo, 2001. Teori Perrtumbuhan Berbasis Ekonomi (Ekspor): Posisi dan Sumbangannya Bagi Perbendaharaan Alat-alat Analisis Regional, Jurnal Ekonomi dan Bisnis Indonesia, Vol.16, No.1, 41-53.

Todaro, M.P, 2000, Economic Development, Seventh Editions, New York, Addition Wesley Longman, Inc. 
